Józef Maria Ruszar

\title{
„Nie skurwiłeś się ani na cal”. Wolność i posiadanie w epistolografii Andrzeja Bobkowskiego
}

\author{
"You Haven't Whored Yourself at All". Freedom and Possession in Andrzej \\ Bobkowski's Epistolography
}

\begin{abstract}
For Bobkowski, maintaining individual freedom grounded in material independence and achieved by one's own work was an essential existential question. The financial freedom and independence were a declaration, a life motto and an economic programme all at once. As a result, the writer's idea came down to changing the status of a political émigré into an economic one who simultaneously stands on the side of freedom for his Country.
\end{abstract}

Keywords: Andrzej Bobkowski, economy in literature, freedom

Streszczenie: Dla Andrzeja Bobkowskiego zachowanie osobistej swobody ugruntowanej w niezależności materialnej, a osiągniętej własną pracą stanowiło zasadniczą kwestię egzystencjalną. Wolność i niezależność finansowa były: deklaracją, hasłem życiowym i programem ekonomicznym zarazem. Idea pisarza sprowadzała się w rezultacie do zmiany statusu emigranta politycznego na sytuację emigranta ekonomicznego, który jednocześnie angażuje się po stronie wolności dla Kraju.

Słowa kluczowe: Andrzej Bobkowski, ekonomia w literaturze, wolność

Tytuł szkicu, wykorzystujący dosadne słownictwo autora Szkiców piórkiem, w tak zwany męski sposób odnosi się do zasadniczej dla Andrzeja Bobkowskiego kwestii egzystencjalnej, to znaczy zachowania osobistej swobody ugruntowanej w niezależności materialnej, a osiągniętej własną pracą. W jednym z listów napomknął: „Mogę sobie o każdej godzinie dnia spojrzeć w lu- 
stro (...) i powiedzieć: »nie skurwiłeś się ani na cal «"1. Tak więc mamy do czynienia z deklaracją, hasłem życiowym i programem ekonomicznym zarazem. Idée fixe pisarza sprowadzała się $\mathrm{w}$ rezultacie do zmiany statusu emigranta politycznego na sytuację emigranta ekonomicznego - tak przynajmniej twierdzi Andrzej Stanisław Kowalczyk ${ }^{2}$, z czym należy się zgodzić z koniecznym podkreśleniem, że nie oznacza to w żadnym razie wyzbycia się prawa, a nawet obowiązku politycznego zaangażowania się po stronie wolności dla Kraju.

Jakiekolwiek układy z komunizmem czy innym totalitaryzmem nie wchodziły w rachubę, choć dopuszczalne metody pisarskiego oddziaływania na czytelnika w zniewolonej Polsce ewoluowały w poglądach pisarza i na przykład w latach czterdziestych Bobkowski publikował na łamach „Tygodnika Powszechnego" i w innych pismach krajowych, ale od czasu socrealizmu - nie. Także istnienie cenzury po tak zwanej odwilży roku 1956 było powodem, dla którego Bobkowski nie zgadzał się na krajowe przedruki, co zresztą spowodowało konflikt z Jerzym Giedroyciem, ponieważ Maison-Laffitte stało na stanowisku, że każda sposobność przekraczania żelaznej kurtyny jest korzystna dla przełamywania komunistycznego monopolu w Kraju. Co ciekawe, pisarz w swojej argumentacji zwracał uwagę nie tylko na polityczną podległość, jaka była wynikiem uzależnienie się od decyzji komunistycznej władzy, ale także na próbę z jej strony ekonomicznego uzależniania pisarzy emigracyjnych i wywierania na nich nacisku finansowego. Ten sposób myślenia, w którym wolność ściśle łączy się z jej ekonomicznymi gwarancjami rozumianymi jako niezależność finansowa, jest bodaj najbardziej charakterystycznym rysem mentalnym Bobkowskiego. Spróbujmy prześledzić ten wątek na kilku przykładach.

\section{Spór z koncepcją romantycznej emigracji}

Pierwszym podstawowym ustaleniem, czy też punktem wyjścia rozważań, musi być status pisarza, który określa specyfikę jego sytuacji. W przypadku Bobkowskiego jest to fakt bycia emigrantem i pisarzem emigracyjnym. Wbrew pozorom nie są to określenia jednoznaczne i domagają się uściślenia, gdyż - jak się okazuje - sam autor Szkiców piórkiem rzecz sprecyzował, a jednocześnie skomplikował.

Zaproponowana przez Bobkowskiego idea „Kosmopolaka” oraz jej nieprzystawalność do klasycznej roli emigracji jest bardzo dobrze opisana w literaturze fachowej, więc tylko rekapitulując, należy powiedzieć, że mamy do

${ }^{1}$ Fragment z listu do W. Jekiela z 10 XII 1948 roku, reprezentanta Klubu Literatury Współczesnej założonego przez studentów polonistyki UW (cyt. za: A.S. Kowalczyk, Wstęp [w:] Andrzej Bobkowski - Aniela Mieczystawska. Listy 1951-1961, Warszawa 2010, s. 19).

${ }^{2}$ Tamże. 
czynienia z poniekąd ironiczną sytuacją, gdyż formalnie wśród tak zwanej żołnierskiej emigracji po drugiej wojnie światowej dominowała koncepcja niezłomnej emigracji politycznej, ale w praktyce była ona niemożliwa do zrealizowania. Tysiące byłych żołnierzy Polskich Sił Zbrojnych na Zachodzie musiało - z konieczności - stać się emigrantami ekonomicznymi, ponieważ po bardzo krótkim okresie nadziei na kolejną wojnę światową utrzymywanie w gotowości jakichkolwiek polskich jednostek militarnych nie wchodziło w rachubę.

Tak więc wbrew deklaracji, że istotą politycznej emigracji jest aktywne kwestionowanie powojennego status quo, życie wymuszało asymilację w kraju osiedlenia, a nie egzystencję zakorzenioną w przyszłości wymarzonej ojczyzny, która w jakiś sposób - na przykład w rezultacie konfrontacji zbrojnej Zachodu ze Wschodem - miałaby odzyskać niepodległość. Na misyjny żywot mogły pozwolić sobie jedynie nieliczne osoby, a ściślej mówiąc, jednostki twórcze, pisarze, dziennikarze w pismach emigracyjnych, nieliczni ludzie kultury oraz niewielka grupa zawodowych polityków, skupionych w emigracyjnych organizacjach lub wokół rządu Rzeczpospolitej Polskiej na uchodźstwie. Cała reszta mogła spełniać wyłącznie funkcję politycznego i materialnego wspomagania emigracyjnych elit. Toteż spór między Bobkowskim a dominującą ideologią emigracyjną dotyczył tylko sposobu istnienia owych elit, a nie emi-

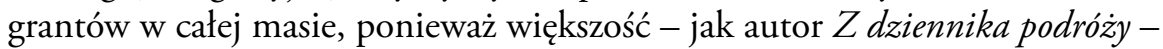
podjęła pracę zarobkową w krajach osiedlenia.

Ale Bobkowski był przecież pisarzem i jego koncepcja dotyczyła właśnie sposobu na życie emigracyjnego artysty czy intelektualisty. Tymczasem Tymon Terlecki - a jego opinię można nazwać obowiązująca - pisał, że „emigracja jest z istoty swej (...) romantyczna, idealistyczna. Emigracja sięga poza istniejącą rzeczywistość, aspiruje do rzeczywistości innej"3. Otóż tego rodzaju rozdwojenie rzeczywistości, które na poziomie politycznej oceny sytuacji było jak najbardziej uzasadnione, absolutnie nie mogło zostać przez Bobkowskiego zaakceptowane na poziomie własnej strategii życiowej. Uważał bowiem, że tylko osobiste osiągnięcia Kosmopolaka, a więc Polaka, który wrasta w społeczność osiedlenia, będą się liczyć w ocenie indywidualnego, spełnionego życia i umocni to też siłę polityczną emigracji jako całości.

Przy czym ten koncept oraz ideał życia wynikał nie tylko z jego ,anarchistycznych skłonności” oraz poglądów na ,życiową krzepę”, ale także z pewnej wizji wolności, która według Bobkowskiego jest iluzją lub samoułudą, jeśli nie została ugruntowana w niezależności ekonomicznej. Materialne zabezpieczenie gwarantowało wolność, również niezależność od łaskawości anglo-amerykańskich sojuszników, o czym będzie jeszcze mowa. W tym sensie Kosmopolak to obywatel świata, który nie stał się ciężarem dla kraju osiedlenia,

3 T. Terlecki, Emigracja walki, „Wiadomości” 1946, nr 2, cyt. za: A.S. Kowalczyk, dz. cyt., s. 19. 
lecz cennym obywatelem, a jeśli jest na dodatek człowiekiem utalentowanym, na przykład artystą, to - jak Fryderyk Chopin czy Joseph Conrad - może wesprzeć swym sukcesem tak zwaną sprawę polską. Paradoksalnie bowiem, postawienie na pierwszym miejscu „spraw uniwersalnych”, a nie „sprawy polskiej”, daje szansę polskiemu artyście emigracyjnemu na sukces, autorytet, a nawet pewien wpływ na opinię publicznąa .

Biorąc pod uwagę, że pojęcie Kosmopolak jest różnie rozumiane, warto zauważyć, że kiedy Bobkowski sam siebie określa i podsumowuje pod koniec życia swoje dokonania, to akcentuje także swój wpływ na tubylców:

Tak więc per saldo pisze do Ciebie człowiek per saldo bardzo szczęśliwy. Miewam nawet nieraz chwile, że czuję się jak Sobieski pod Wiedniem. Dałem sobie radę, zbudowałem tu nowe życie z niczego, życie wolne, pełne swobody, wyrobiłem sobie szacunek ludzi, wychowałem już cały zastęp młodych ludzi, dla których słowo „Polonia” nie jest pustym dźwiękiem. Poznali ją przeze mnie na tyle, na ile to możliwe. Gdzieś, kiedyś, może się to przydać.

Nie bez znaczenia dla tych słów jest to, że pisze to człowiek w obliczu bliskiej, a spodziewanej śmierci. Warto też może zauważyć, że list adresowany jest do ówczesnego redaktora „Tygodnika Powszechnego”, Jerzego Turowicza, a część sformułowań przypomina sławne wyznanie św. Pawła, rozpoczynające się od słów: „W dobrych zawodach wystąpiłem, bieg ukończyłem, wiary ustrzegłem" (2 Tm 4,7).

Podkreślmy, że zarówno explicite wyrażane opinie, jak i podane przykłady zrealizowanej postawy Kosmopolaka (zwłaszcza Conrad jest istotnym wzorcem), akcentują nie tylko niezależność ekonomiczną, ale także jego wrośnięcie w świat, w którym przyszło mu żyć na emigracji. Bobkowski uważa, że formuła Terleckiego, z którą polemizuje, jest modelem schizofrenicznym oraz sprzeczna z życiem i w tym sensie demoralizująca ${ }^{6}$. Nic więc dziwnego, że $\mathrm{w}$ listach do Giedroycia i do innych adresatów tak często opisuje proces swego wrastania w lokalną społeczność: „Ja tu zapuszczam korzenie, tysiąc problemów dla mnie bardzo istotnych, drobnomieszczańskich, wam wydaje się (...) bez znaczenia (...). A ja (...) pomimo wszystko staram się nawrócić do tego normalnego życia, o którym w ciągu tych lat zdołałem zapomnieć (...)"’

${ }^{4}$ Koncepcja ta wyraziście została przedstawiona w szkicu Biografia wielkiego Kosmopolaka, „Kultura” 1960, nr 9 (155), http://static.kulturaparyska.com/attachments/cb/b0/4389fdd1 ef0 3ab9dd13faf07db8cccde93451e83.pdf\#page=11, dostęp: 28.11.2015.

5 A. Bobkowski, Listy do Jerzego Turowicza 1947-1960, oprac. M. Urbanowski, Warszawa 2013, s. 112.

${ }^{6} \mathrm{Na}$ argument o demoralizującym aspekcie tak rozumianej idei emigracji i sprzeciw Bobkowskiego wobec dwóch rzeczywistości wskazuje A.S. Kowalczyk (zob. tenże, dz. cyt., s. 20).

7 J. Giedroyc, A. Bobkowski, Listy 1946-1961, Warszawa 1997, List 13, s. 63. 
Jak już wspomniałem, to przeciwstawienie nie jest oczywiste i przyjdzie do niego jeszcze wrócić, ponieważ tak rozumiana opozycja normalnośćlemigracja nie dotyczyła przecież szerokich rzesz byłych żołnierzy 2. Korpusu i innych polskich jednostek zbrojnych. Ci żołnierze na ogół postępowali podobnie jak Bobkowski, to znaczy zaaklimatyzowali się w Anglii czy Stanach Zjednoczonych, idąc do pracy lub zakładając własne biznesiki, a nawet biznesy. Jeśli sytuacja Bobkowskiego była nieco inna, to z tego powodu, że w Gwatemali samotnie walczył o byt, z dala od emigracyjnych skupisk. Toteż zarzut antynormalności dotyczył w gruncie rzeczy - by tak powiedzieć - „zawodowych emigrantów", o których w cytowanym liście powiada, że żyją w klimacie „wiecznej niepewności” niczym członkowie „trupy wędrownego cyrku”.

\section{Bycie pisarzem niezależnym}

$\mathrm{Na}$ koncepcję własnej tożsamości Kosmopolaka wpłynęła jeszcze wizja swojej niezależności jako pisarza. I chociaż nie da się całkowicie rozdzielić tych dwóch pojęć, to dla jasności wywodu należy rzecz omówić osobno. Otóż Bobkowski ceni sobie tych ludzi pióra, którzy czerpią materiał dla twórczości z tak zwanego życia, czyli osobistego doświadczenia pisarza. Nie darmo Conrad jest tu ikoną wszelkiego pisarstwa i ideałem, oczywiście nie w znaczeniu jakiegoś bezpośredniego wpływu na twórczość Bobkowskiego, ale z powodu tkania materii powieściowej z osobistego przeżycia i wiedzy zawodowej'. Pisarstwo Conrada nie jest więc wprawką stylistyczną, lecz studium przemyślanej egzystencji. Bardzo podobnie referuje swoje poglądy Bobkowski w liście do matki, Stanisławy Bobkowskiej: „Za wiele teraz się dzieje, jest zbyt wielkie parcie ku niemyśleniu, aby bawić się tylko w formę. A zresztą ludzie pragną myśli - tej ludzkiej i ciepłej” ${ }^{10}$. Charakterystycznym rysem jego pisarstwa, ale też i przekonań na ten temat jest konieczna znajomości techniki przez współczesnych pisarzy ${ }^{11}$.

Otóż sam Bobkowski niewątpliwie posiadał talent dokumentalisty i nic dziwnego, że do szczytowych osiągnięć jego pisarstwa należą dwa tomy diarystyki (Szkice piórkiem i $Z$ dziennika podróży) oraz listy. W jednym i drugim wypadku mamy do czynienia z formami pośrednimi, hybrydowymi, trudnymi do zakwalifikowania gatunkowego, gdyż i epistolografia, i zapiski autora $Z$ dziennika modelarza są w gruncie rzeczy połączeniem reportażu z esejem,

8 Tamże.

9 Jedynie opowiadania z Coco de Oro zdradzają Conradowską inspirację. Nie ma jej natomiast w największych osiągnięciach pisarskich Bobkowskiego, jakimi są formy dokumentalne, pokrewne dziennikarstwu i diarystyce, to znaczy w Szkicach piórkiem i w $Z$ dziennika podróży.

10 List z 29 czerwca 1947 roku, cyt. za: A.S. Kowalczyk, dz. cyt., s. 34 (cytowany list znajduje się w Archiwum Instytutu Literackiego Maisons-Laffitte i nie wszedł do tomu korespondencji z matką: A. Bobkowski, Listy z Gwatemali do matki, red. E. Jurczyszyn, Warszawa 2008).

11 A. Bobkowski, Listy do Jerzego Turowicza..., dz. cyt., s. 59-61. 
bez względu na gatunkowe zaszeregowanie. Można przypuścić, że gdyby Bobkowski został dziennikarzem, jego miejsce byłoby gdzieś między Melchiorem Wańkowiczem a Ryszardem Kapuścińskim. Talent pisarza-dokumentalisty nie został rozwinięty, ponieważ nie zdecydował się na zawodowstwo i do końca życia pozostał pisarzem-amatorem, preferującym inne źródła utrzymania.

Decyzja ta wynikała zarówno z niewiary w swój talent powieściowy, jak i obawy przed utratą niezależności. Bał się bowiem finansowego uzależnienia, i nie bez racji. Zarówno jego intelektualna niezależność, jak i pamfletowy styl (widoczny przede wszystkim w listach) dobitnie wskazują, że miałby poważne kłopoty z emigracyjnymi czytelnikami - o wiele większe niż wspomniany Melchior Wańkowicz, który wprawdzie był noszony na rękach za wielki reportaż o bitwie pod Monte Cassino, ale tym gwałtowniej odrzucony po tomie esejów i felietonów zatytułowanych Kundlizm. Kontrowersyjna publicystyka zamieszczana w „Kulturze” i krytyczny stosunek do pewnych przejawów życia emigracyjnego zdają się świadczyć, że cięte pióro Bobkowskiego przysparzałoby mu wielu wrogów. Na koniec jeszcze jeden - przyznajmy, że zasadniczy - argument przeciwko podjęciu pracy dziennikarza i reportażysty: nierozwinięty rynek wydawniczy. Nieliczne i słabe ekonomicznie polskie pisma emigracyjne nie zachęcały do podjęcia tej ścieżki kariery zawodowej.

Okazjonalność jego pisarstwa była ceną za niepodleganie środowiskowej cenzurze oraz łaskawości kulturalnych i politycznych fundacji. Była to postawa kompletnie niezrozumiała dla kogoś, kto cenił sobie dorobek pisarski autora i chciał mu stworzyć warunki do pracy twórczej ${ }^{12}$. Niestety, nie zachowały się listy Anieli Mieczysławskiej i dysponujemy wyłącznie argumentacją samego Bobkowskiego, ale wynika z nich jasno, że pisarz musiał walczyć z podziwiającym go otoczeniem, które na gwałt chciało go uszczęśliwić stypendiami twórczymi. Początek znajomości z Mieczysławską przecież stąd się bierze, że mieszkająca w Nowym Jorku działaczka emigracyjna na prośbę Giedroycia stara się wdusić w pisarza stypendium amerykańskiej fundacji, a pisarz stanowczo odmawia. Zostawmy na chwilę kwestię strategii Bobkowskiego jako pracownika, któremu ten rodzaj pomocy zaburzyłby misterny plan stworzenia własnego biznesiku z modelami samolotów, bo to inna sprawa. Zwróćmy uwagę na wolnościową retorykę autora $Z$ dziennika modelarza:

12 „W moim ostatnim liście, a i w poprzednich, dawałem im jasno do zrozumienia, że ja żadnej pomocy nie chcę. Być może, że nie rozumieli mnie, w każdym razie przed dwoma miesiącami objawiłem tę moją wolę kategorycznie. Obawiam się jednak, że oni, powodowani jedynie wielką przyjaźnią dla mnie i może zaniepokojeni pewnymi akcentami neurastenii z mojej strony, postanowili pomimo wszystko mnie "ratować« i zgwałcić. Tymczasem to jest zupełnie niemożliwe. Ja żadnej pomocy nie tylko w tej chwili nie chcę, ale nawet gdyby mi ją przyznano, nie mógłbym jej przyjąć. Mam nadzieję, że Pani, jako kobieta, a więc istota chodząca po ziemi, a nie w obłokach, zrozumie moje motywy". Andrzej Bobkowski - Aniela Mieczystawska..., dz. cyt. s. 39-40. 
Jeśli zdecydowałem się wyjechać z Europy, to m.in. powodami jednym z wybitnie decydujących była chęć odczepienia się właśnie od ciągłego życia z takich lub innych funduszów, od skakanki funduszowej, która na pewno mi groziła (...), siedzenie na funduszach i odczuwam to jako pewnego rodzaju skrępowanie. Człowiek siedzący na jakimkolwiek funduszu jest zawsze trochę utrzymankiem ${ }^{13}$.

I dalej zrozumienie dla kogoś, kto ma jakąś pracę naukową lub artystyczną i musi znaleźć środki na przeżycie. Ale sam dba głównie o to, aby się nie uzależnić od swoich czy obcych, ponieważ zna stopień uzależnienia wspomnianego już Wańkowicza czy wstrzymanie prenumeraty „Kultury” przez obrażoną część emigracji. Do Anieli Mieczysławskiej pisze: „A zresztą ja mam gdzieś, czy się ktoś obrazi, od 1939 roku ciagle musiałem uważać, aby nie obrazić jakiś obcych, najpierw Francuzów, potem własną swołocz, a teraz znowu Amerykanów. Bo dają" ${ }^{14}$. We wspomnianym liście, pełnym gniewu na emigrację, która nie potrafi zapewnić utrzymania starzejącym się wybitnym polskim pisarzom, Bobkowski silnie podkreśla, że dlatego też nie chce brać pieniędzy od Amerykanów, iż dzięki temu może szczerze i bez zażenowania pisać o nich dobrze, a nawet z zachwytem.

Jednym z powodów, dla którego pisanie nie było dla niego czynnością najważniejsza, okazał się witalizm Bobkowskiego. Także w tym sensie nie był pisarzem zawodowym, gdyż twórczość nie była dla niego czymś, bez czego nie mógłby żyć: „U mnie sztuka i literatura swoją drogą, a życie, papu, cudowne życie, wspaniałe życie przede wszystkim. Dla mnie samo życie jest największą sztuką i rzeczą najbardziej wartą zachodu"15. Wydawał się całkowicie pozbawiony pisarskiej ambicji - stąd jego odmowa przyjęcia członkostwa Związku Pisarzy Polskich na Obczyźnie ${ }^{16}$. Nie nęciła go również szansa zawodowego pisarstwa przez zaczepienie się w jakimś czasopiśmie: „Ja muszę po dziurki od nosa siedzieć w życiu i w ogóle mogę tylko wtedy pisać, kiedy mogę nie pisać” - odpowiedział na propozycję współpracy z tygodnikiem „Odrodzenie” 17 . Jego witalizm i pogarda dla wybujałego intelektualizmu, legendarna wręcz niechęć do wszelkich idei i ideologii, a - co za tym idzie - twórców przedkładających sztukę nad egzystencję oraz abstrakcje nad konkretem spowodowały

13 Tamże, s. 40.

14 Tamże, s. 82.

15 Tamże, s. 114.

16 A. Bobkowski, Listy do Tymona Terleckiego 1956-1961, oprac. N. Taylor-Terlecka, Warszawa 2006, s. 69.

17 List z 1947 roku do matki, cyt. za: A.S. Kowalczyk, dz. cyt., s. 34 (również ten list znajduje się w Archiwum Instytutu Literackiego Maisons-Laffitte i nie wszedł do tomu korespondencji z matką: A. Bobkowski, Listy z Gwatemali do matki, dz. cyt.). 
ostrą reakcję wielu pisarzy i intelektualistów. Odpowiedzią na publikację jego listów (już po śmierci pisarza) były zarzuty o - między innymi - faszyzm ${ }^{18}$.

\section{Europa przeżarta totalizmem}

Jednym $\mathrm{z}$ istotnych argumentów za opuszczeniem Francji był brak wolności zanik dawnego republikańskiego ducha. Obecny stan rzeczy wydaje się tragiczny: „ta cała Europa to już zupełna degrengolada” ${ }^{19}$ - podsumowuje krótko Bobkowski, a w wielu innych miejscach argumentuje dokładniej, na przykład wyśmiewa intelektualne wpływy lewicy w gospodarce:

Obecnie powróciłem do moich fachowych zainteresowań - do ekonomii. Siedzę teraz nad zbiorem artykułów wszystkich sławnych ekonomistów pt. L'économie dirigée en regime collectiviste [Ekonomia sterowana w gospodarce kolektywnej- J.M.R.]. W międzyczasie przekonujemy się o jej wynikach na własnej skórze ${ }^{20}$

- informuje Bobkowski matkę w lutym 1946 roku. A opisy konkretnych skutków wprowadzania elementów gospodarki socjalistycznej przez socjalizujące rządy francuskie znajdujemy w jego notatkach zatytułowanych $Z d z i e n-$ nika podróży. A za co lubi Amerykę Południową, a konkretnie swoją nową ojczyznę? Za to, że - dzięki amerykańskiej interwencji - nie zwyciężył w niej kolektywizm, a także za brak omnipotencji państwa. W przeciwieństwie do Francji, gdzie na każdym kroku obywatele są kontrolowani, w Gwatemali żyje się bez ciągłej kurateli:

Wyjeżdżając z Europy, przysiągłem sobie, że nie będę stał w ogonku, że nie będę się pchał i że jeżeli umrę, to nie w tłumie i nie jako socjalnie ubezpieczony. Tutaj, jak tylko w autobusie jest więcej ludzi, nie pcham się - czekam. Mój dowód osobisty gwatemalski zamknąłem w żelaznym pudełku, klucz wyrzuciłem i od trzech lat chodzę bez jednego papierka przy sobie ${ }^{21}$.

Prawdziwy dramatyzm tego wyznania ukaże się czytelnikowi wówczas, kiedy uzmysłowi sobie, że autor listu opisuje stan rzeczy z grudnia 1951 roku. Brak konieczności stania w ogonku, a przede wszystkim możność poruszania się bez paszportu czy dowodu osobistego jako przejaw swobody została w sa-

18 Takie sugestie zawiera między innymi wypowiedź Miłosza (C. Miłosz, Uwagi do uwag Gombrowicza, „Kultura” 1962, nr 12, s. 124, za: K. Ćwikliński, Furor scribendii albo O pamfletowym charakterze listów Andrzeja Bobkowskiego [w:] A. Bobkowski, Listy do różnych adresatów, red. K. Ćwikliński, Kraków 2013, s. 7-8.

${ }_{19}$ Andrzej Bobkowski-Aniela Mieczystawska..., dz. cyt., s. 54.

20 A. Bobkowski, Listy z Gwatemali do matki, dz. cyt., s. 18.

${ }^{21}$ Tamże, s. 47. 
mych listach do Mieczysławskiej przytoczona co najmniej trzykrotnie w kilkuletniej korespondencji, przy czym w 1960 roku Bobkowski pisze, że przez 12 lat pobytu w Gwatemali nikt go jeszcze nie wylegitymowa22 ${ }^{22}$. Zwłaszcza ukochana Francja w oczach Bobkowskiego stała się półtotalitarnym krajem leni, którzy wolność osobistą przehandlują za pakiet socjalny, a cały plan Marshalla jest nieporozumieniem, ponieważ pozwoli na utrzymanie znacjonalizowanej i niewydajnej gospodarki:

Pchać miliony w to upaństwowione i znacjonalizowane marnotrawstwo produkcyjne takiej Francji np., to rzeczywiście zaczyna graniczyć z brakiem zdrowego rozsądku. I to pchać ciężkie pieniądze na to, żeby tam wszyscy jeszcze się kulturalnie wykrzywiali pod adresem Amerykanów. Pracuj na nich, bij się za nic - wszystko tylko dlatego, że tam są te katedry i trochę obrazów. Cholera z nimi i już²3.

Podobnie wyraża się o pomyśle Polaków na emigracji, by naciskać Amerykanów na objęcie planem Marshalla także Polski. Dlaczego? Ponieważ finansowanie „surrealistycznej gospodarki półinteligentów doktrynerów” ${ }^{24}$ jest idiotyzmem, a nie „polską racją stanu”. Warto przy tej okazji zauważyć, że to opinia kogoś, kto ukończył ekonomię, a nie tylko przeciwnika politycznego komunizmu. W listach do matki znajdujemy argument przeciwko istocie socjalistycznej doktryny, która nie bierze pod uwagę natury ludzkiej:

Mnie czytanie tych pism krajowych doprowadza do lekkiego zawrotu głowy. To czysty surrealizm to wszystko, co się u nas dzieje. Jak można, mając na każdym kroku próbki zupełnej bezużyteczności, zupełnej klapy systemu zwanego „socjalizmem", dyskutować równocześnie o jego wyższości nad innymi i wierzyć, że w tym systemie może być inaczej. To Kościół katolicki nie wyprodukował więcej niż jednego świętego na rok i ma ich coś jednak poniżej dwóch tysięcy, a ci panowie teoretycy marksizmu chcieliby, żeby produkować świętych milionami, żeby ludzie nie kradli, żeby pracowali wydajniej, żeby byli bardziej „uspołecznieni” etc. To napawa przerażeniem, bo zakrawa na szpital wariatów. Przecież w TYM systemie ludzie MUSZĄ kraść, ludzie muszą być egoistami i diabłami, bo ten system niczego nie rozwiązuje i nie rozwiąże ${ }^{25}$.

I dalej mimochodem stwierdza, że 40 lat komunizmu w Rosji świadczy o niebywałym bogactwie tego kraju oraz... nieustannej pomocy „schyłkowego kapitalizmu", który nie pozwala sowieckiej gospodarce umrzeć śmiercią natu-

22 Tamże, s. 158, 164.

${ }^{23}$ Tamże, s. 55. Podobna uwaga w: A. Bobkowski, Listy do Jerzego Turowicza..., dz. cyt., s. 45.

${ }^{24}$ Andrzej Bobkowski-Aniela Mieczystawska..., dz. cyt., s. 107.

25 A. Bobkowski, Listy z Gwatemali do matki, dz. cyt., s. 208-209. 
ralną. Opinia ta została wypowiedziana w roku 1957, a więc na wiele lat przed upadkiem ZSRR. Bobkowski uważa, że łapownictwo, nadużycia i złodziejstwo należą do istoty systemu i dlatego śmieszą go różne akcje „walki z łapownictwem", o których czyta w prasie PRL ${ }^{26}$.

\section{Wrastanie w Gwatemalę}

Jak zostało już powiedziane, idée fixe pisarza na punkcie swej niezależności i wolności prowadziła do zmiany statusu emigranta politycznego na sytuację emigranta ekonomicznego. Nie był to przypadek, ale świadoma strategia. Również witalność czy też ukochanie normalnego życia (cokolwiek by to miało precyzyjnie znaczyć) skłaniały do wrastania w lokalną społeczność. Widać to nie tylko w czasie, kiedy Gwatemala stacza się w objęcia komunistów i Bobkowski gotów jest z pistoletem w garści bronić się przed uzbrojoną gwardią robotniczą plądrującą zamożniejsze domy ${ }^{27}$, ale także gdy daje dowód fascynacji swą nową ojczyzną w listach. Otóż kiedy młodzi ludzie z Polski, stosując zwyczajowe wyobrażenie o rozszczepieniu serca emigranta, dopytują o jego emocjonalne rozdarcie, odpowiada im brutalnie: „żeby nie bredzili na nutę trzech wieszczów (...), bo ciałem i sercem jestem w Gwatemali, a tylko głową trochę w Polsce"28. Podobnie w liście do Jerzego Turowicza, napisanym niedługo przed śmiercią: „Dziś rozumiem, że można jakiś obcy kraj pokochać i bez uszczerbku na duszy mieć jakby dwie ojczyzny" 29 .

Przede wszystkim listy do wielu adresatów (a Bobkowski był epistolografem namiętnym) oraz znakomity reportaż zatytułowany $Z$ notatek modelarza są pełne zachwytów nad Ameryką Środkową oraz Stanami Zjednoczonymi. Nie ma najmniejszej wątpliwości, że autor nie tylko akceptuje swych współobywateli i jest zachwycony amerykańską mentalnością, ale także że wspaniały kontynent odkryty przez Kolumba uważa za miejsce poniekąd cudowne, by nie powiedzieć rajskie. Wprawdzie i do raju - jak wiemy - zakrada się wąż,

26 Tamże, s. 211.

27 „Ostatnie wypadki tutaj były bardzo interesujące. Miałbym Pani sporo do powiedzenia. Jeszcze ciągle sypiam z moim coltem przy łóżku, a przedwczoraj wieczorem w lasku bambusowym koło mojego domu przez godzinę osaczali dwóch komunistów i prali z karabinów maszynowych, jak ja w tej chwili na maszynie do pisania. Ale daliśmy im radę. Ja czuję się teraz dosłownie bardziej wolny i wesoły niż po uwolnieniu Paryża. To był już gruby węzeł, pachniało amerykańską Koreą albo Indochinami” (Andrzej Bobkowski - Aniela Mieczystawska..., dz. cyt., s. 60). Podobne opisy można znaleźć w $Z$ dziennika modelarza.

${ }_{28}$ Andrzej Bobkowski-Aniela Mieczystawska..., dz. cyt., s. 107.

${ }^{29}$ A. Bobkowski, Listy do Jerzego Turowicza..., dz. cyt., s. 108. Deklaracja ta jest podważana przez niektórych badaczy, na przykład Michał Kopczyk pisze stanowczo: „Gwatemala, którą wybrał jako ostateczny cel i koniec cyklu swych życiowych zerwań, nie stała się dla niego nigdy ojczyzną, nie zyskała rangi osobistego środka świata”. M. Kopczyk, Obecność innego. Studia z literatury wspótczesnej, Bielsko-Biała 2013, s. 41. 
więc niedostatki mentalne i moralne potomków konkwistadorów są przyjmowane ze zrozumieniem, choć bez łatwego rozgrzeszenia, zwłaszcza jeśli chodzi o pracowitość (zarzut dość charakterystyczny dla mentalności pisarza będącego pracoholikiem $)^{30}$. Nie wchodząc w szczegóły, stwierdźmy więc dobitnie, że w porównaniu ze starą, zarozumiałą Europą zachodnia hemisfera wypada celująco i godna jest żarliwej miłości.

Bez względu na to, jak wiele jest w listach Bobkowskiego pozy, kiedy zaklina się, że nie tęskni za Polską, że w Gwatemali odniósł sukces finansowy, albo że przedkłada zwykłe życie nad dolę i prestiż pisarza - kwestia ekonomicznej niezależności wydaje się najważniejsza i traktowana ze śmiertelną powagą. Dowodem jest odrzucanie propozycji przeniesienia się do Nowego Jorku lub Monachium. W pierwszym wypadku pokusa pochodziła od Kazimierza Wierzyńskiego i mowa była o pensji w wysokości 600 dolarów, a w drugim - dobrze płatna praca w Wolnej Europie.

O ile powrót do Europy wydawał się mniej atrakcyjny ze względu na zawód, jaki pisarzowi sprawił rodzinny kontynent, o tyle zamieszkanie w podziwianych Stanach Zjednoczonych mogło go fascynować. Dlaczego więc pisarz odmawiał, a życzliwi przyjaciele z trudem rozumieli jego postawę? W listach do matki tłumaczył swoje stanowisko jasno i wyraźnie: „Musiałem mu [Wierzyńskiemu - J.M.R.] długo klarować, że tak ciężko wywalczonej wolności i niezależności (...) nie rzuca się lekko"31. Przy okazji rezygnacji z propozycji pracy w Radio Wolna Europa dzieli się z matką obserwacjami na temat braku zrozumienia dla swojego stanowiska: „Z rosnącym strachem konstatuję, że ludzie zaczynają nie rozumieć, co to znaczy, że "chcę być wolnym"”32. Przypomina jak wielką wartością jest dla niego osobista niezależność, zdobyta tak dużym wysiłkiem: „A między nami, ja jestem bardziej dumny z tych dziesięciu lat »niedania się" i z tej sklepiczyny niż z wszystkich wypocin, które napisałem" 33 .

O ile ostatnie zdanie wypada uznać za chwyt retoryczny, gdyż - wbrew deklaracjom - Bobkowskiemu imponowała pisarska sława, to trudno zignorować dumę z osiągniętego sukcesu gospodarczego i zapewnienia sobie materialnej niezależności. Listy do matki naprowadzają na jeszcze jeden trop miłości do nowego kraju osiedlenia: zauroczenie przyrodą Gwatemali. Jest to jednak osobne zagadnienie.

${ }^{30}$ A. Bobkowski, $Z$ notatnika modelarza [w:] tegoż, $Z$ dziennika podróży, Warszawa 2013, s. $143-144$.

31 Tenże, Listy $z$ Gwatemali do matki, dz. cyt., s. 214.

32 Tamże.

33 Tamże, s. 215. 


\section{Mieszczańskie cnoty}

Wolność rozumiana jako ekonomiczna niezależność była ideą w różny sposób przez Andrzeja Bobkowskiego uzasadnianą, choć wachlarz tych argumentów okazuje się wcale nie tak mały. Jednym z nich jest zwyczajny antykomunizm. Komunizm dla autora Coco de Oro posiadał dwa wstrętne wymiary: polityczno-policyjną zależność prowadzącą do moralnej degrengolady oraz ekonomiczny walor niewolnictwa. Oba elementy systemu wzajemnie się wspomagały $^{34}$.

W jednym z pierwszych listów do Turowicza pojawia się wzmianka o radości wynikające z tego, że „strząsnął” z siebie swe dotychczasowe życie w Europie, a jednocześnie, że niektórzy tego faktu nie rozumieją. Do takich zalicza Jarosława Iwaszkiewicza, który ubolewał: „I pomyśleć, że taki człowiek jak ty musi strugać wiatraczki”. Cytując to zdanie Turowiczowi, Bobkowski relacjonuje swoją złośliwą odpowiedź: „Wolę strugać to niż co innego” ${ }^{35}$. Dramatyzm tej wypowiedzi staje się jaśniejszy, jeśli weźmie się pod uwagę podziw, jakim Bobkowski za młodu otaczał Iwaszkiewicza ${ }^{36}$.

Ale komunizm był dla Bobkowskiego zaledwie ekstremalnym przypadkiem. To stara Europa okazała się niegodna swej własnej tożsamości i dlatego pisarz szukał szczęścia na krańcach świata. Zapłacił za to wielkim wysiłkiem i sporym wyrzeczeniem, ale znał cenę i nie wahał się. Myślę, że najdobitniej wyraził to w szczerym liście do stryja, napisanym 4 stycznia 1940 roku, a więc zaledwie w kilka miesięcy po przybyciu do Gwatemali:

Kochany i Drogi Stryjku!

Już minęło pół roku, gdy napisałem do Ciebie ostatni list. Nie pisałem tak długo, bo brakło i czasu, i pieniędzy. Te „głupie” 36 centów, które kosztuje najlżejszy list lotniczy, to dla nas 5 funtów cukru, albo 36 bułek, albo 4 funty kartofli, albo 3 funty ryżu, albo 3 paczki dobrych papierosów, albo funt najlepszej kawy, albo kosz jarzyn i owoców, albo bardzo wiele rzeczy. Niestety, nasze dotychczasowe zarobki są

${ }^{34}$ Ciekawe pod tym względem są uwagi na temat etapów wprowadzania komunizmu w Gwatemali (A. Bobkowski, $Z$ notatnika modelarza, dz. cyt. s. 142-172).

${ }_{35}$ Tenże, Listy do Jerzego Turowicza..., dz. cyt., s. 48.

36 Zasadniczy zwrot nastąpił po zjeździe szczecińskim w 1949 roku, podczas którego zaanonsowano tak zwany socrealizm. W liście do Giedroycia napisze: „Iwaszkiewicz zupełna kurwa - przynajmniej z tego, co mnie dochodzi z »Tygodnika Powszechnego «. Przestałem do niego pisać już od półtora roku. Na zeszłe święta wysłałem mu jeszcze kartkę z życzeniami, ale nie odpisat. I lepiej" (J. Giedroyc, A. Bobkowski, Listy 1946-1961, dz. cyt., s. 180). Samemu Iwaszkiewiczowi tak odpisał: „Nie żałuj mnie. Co mam robić? Pisać? Ja wiem, że nic wielkiego nigdy nie napiszę. Czy sądzisz, że siedzenie w jakimś biurze byłoby lepsze. Brrr - nie znoszę biur. Ja jestem, godło Guatemali - ich ptak, quetzal. Istnieją tylko wypchane okazy, bo żywe, w klatce, zdychają po kilku dniach. A ja nie mam ochoty zdechnąć i żeby mnie oglądali wypchanego”. A. Bobkowski, „Tobie zapisuje Europę". Listy do Jarostawa Iwaszkiewicza, oprac. J. Zieliński, Warszawa 2009, s. 75. 
jeszcze takie, że nawet 5 centów jest pozycją, cóż dopiero 36. Dlatego nie gniewaj się na mnie. Ograniczyliśmy się do najkonieczniejszych listów; ja do mamy, Basia do swojej mamy i do Jaśka w Paryżu, a i to rzadko. Za to jak dotąd, nic nie żałujemy. Wprost przeciwnie. Zapracowani, zmęczeni, niemogący sobie pozwolić na „extra”, gratulujemy sobie tej decyzji niemal co wieczór. Co ci będę mówił. Ja przede wszystkim cenię sobie wolność, a ostatnio nawet w Paryżu zacząłem czuć się jak w klatce. Zresztą nie będę się rozpisywał, bo może przeczytasz w jednym z najbliższych numerów „Kultury”, co o tym myślę

Pean na cześć osobistej niezależności, która przecież nie jest sytuacją darmową, napisany został w sytuacji społecznej, kiedy środowiska polskiej emigracji politycznej same zastosowały cenzurę wobec paryskiej „Kultury”, karząc ją za nieprawomyślne artykuły, w tym teksty Bobkowskiego. Miesięcznik wycofano ze sprzedaży w placówkach londyńskiej emigracji, co oburzyło pisarza, który porównał tę sytuację do bierutowskiej Polski. Ale w ocenie Bobkowskiego komunizm był tylko szczególnym przypadkiem zgody na polityczne niewolnictwo, o które oskarżał także społeczeństwo zachodnich krajów europejskich. Był to jeden z argumentów na rzecz wyjazdu. We wspomnianym w liście do stryja artykule pisał:

Europa to przede wszystkim jej człowiek. A - trudno i darmo - gatunek tego człowieka psuje się ostatnio z zatrważającą szybkością. Europejczyk zamienia się w pacotille, barana, traci wszystkie te cechy, które stanowiły o jego wyższości dawniej: przedsiębiorczość, pęd do rozsądnego ryzyka, zdolność do indywidualnego sądu, rozsądne nieposłuszeństwo. Wprost przeciwnie - stał się posłuszny Państwu i Państwom obcym. Stoi dziś cierpliwie w ogonkach, wypełnia skrupulatnie dziesiątki formularzy, onanizuje się biernym krytycyzmem i intelektem jako namiastkami życia ${ }^{38}$.

Najbardziej szydercze zdania tego opisu dotyczą Francji - niegdysiejszego symbolu obywatelskich praw, rewolucyjnej dumy i... pracowitości. Załamanie się wiary w dawną Francję chyba najdobitniej zostało wyrażone właśnie na poziomie etosu pracy:

jeden z moich kolegów robociarzy, Włoch, uzyskał naturalizację. Poszedł do starego zawiadomić go o tym. Stary mu pogratulował i powiedział: „Mam nadzieję, że

37 A. Bobkowski, Listy do Aleksandra Bobkowskiego 1940-1961, oprac. J. Podolska, Warszawa 2013, s. 46-47. Bobkowski często czyni szczegółowe uwagi na temat kosztów życia, czasami w kontekście tego, czy stać go na coś, na przykład na wysłanie listu. Podobnie tłumaczy się z ograniczenia korespondencji do Iwaszkiewicza: „Będę musiał się streścić na tej jednej stronie, bo każdy gram listu kosztuje, a my jeszcze nie zarabiamy. Tu nie tylko 36 centów (cena listu), ale głupie 5 centów jest pieniądzem, za który można kupić wiele rzeczy”. A. Bobkowski, „Tobie zapisuje Europe”..., dz. cyt., s. 63.

38 Tenże, Na tytach [w:] Coco de Oro, Paryż-Kraków 2015, s. 75. 
pomimo iż jesteś Francuzem, to pracować będziesz dalej tak jak Włoch”. I to zupełnie poważnie. W tym zawiera się wszystko - cała Francja $\mathrm{a}^{39}$.

Nie jest też przypadkiem, że jako jeden z kardynalnych zarzutów pod adresem Europy (a jej symbolem pozostaje Francja) pojawia się pogarda dla pracy i twórczej wynalazczości technicznej. Bobkowski uważa to za zdradę cywilizacyjnego nastawienia starej Europy i przeciwstawia jej postawę Amerykanów. Jak zwykle u Bobkowskiego zarzut sformułowany został polemicznie i na konkretnym przykładzie:

Śmiejemy się z Amerykanów, że są „głupi”, że nie są w stanie nas „zrozumieć” itp. Wcale się nie dziwię. Sam powiedz, czy ludzie, którzy do cna wyniszczyli moskity w całej strefie Kanału Panamskiego - czy ci ludzie mogą zrozumieć ludzi, którzy nie zdobyli się na wytępienie komarów nawet w Juan les Pins i równocześnie puszą się ze swoją kulturą (40 $^{40}$

I dopiero na tym tle rozpływa się nad zaletami klimatyzacji albo możliwością spania przy otwartym oknie bez moskitiery, skoro uporano się z plagą owadów. Cytowany list wskazuje nie tylko na sposób patrzenia na świat według kryteriów stosunku do cywilizacji, ze szczególnym uwzględnieniem rozwoju technicznego i ekonomicznej zapobiegliwości, ale także wiele mówi o skomplikowanej grze autokreacyjnej pisarza, który wobec rozlicznych swych korespondentów odgrywa nieco inną rolę, dostosowaną do konkretnego epistolografa, ale z zachowaniem pewnych cech stałych budowanego wizerunku. Jak pisze Michał Kopczyk:

Świadom znaczenia tej gry i reguł, jakie nią rządzą, Bobkowski wykorzystuje okazję, tocząc walkę o własny wizerunek jako twórcy, o własną ważność, stwarzając się od podstaw, swój los emigranta osiadłego w odległym kraju przerabiając w sytuację człowieka spełnionego, a przy tym świadomego swego znaczenia i miejsca w świecie. Tę strategię urzeczywistnia Bobkowski zarówno w korespondencji z wielkimi i prominentnymi spośród swoich współczesnych, jak i z tymi mniej znanymi ${ }^{41}$.

Trudno zaprzeczyć autokreacyjnej potrzebie w epistolografii, szczególnie jeśli chodzi o wrażenie męskiej krzepy czy nieustannego podkreślania swego - umiarkowanego przecież - sukcesu, ale raczej nie odnosi się ona do zbioru $Z$ dziennika modelarza, zwłaszcza tej części, która dotyczy zachwytów nad amerykańskim kapitalizmem, a ściślej mówiąc, zauroczenia kulturą biznesu. Pochwały są jak najbardziej bezinteresowne. Wynikają nie tylko ze sprzeciwu

\footnotetext{
39 Tenże, „Tobie zapisuje Europe”..., dz. cyt., s. 32.

40 Tamże, s. 65.

${ }^{41}$ M. Kopczyk, dz. cyt., s. 37.
} 
wobec obaw, że cywilizacja techniczna „zabija poezję”, gdyż zdaniem pisarza nie technika jest zagrożeniem dla literatury, ale oschłość serca ${ }^{42}$.

Przede wszystkim Bobkowski z lubością opisuje pracowitość, fachowość i dbałość o klienta przez niewielkie firmy, często rodzinne, które pielęgnują wysoką jakość produktu i nie ulegają pokusie łatwego, choć jednorazowego zarobku, ale przeciwnie - nastawiają się na długotrwałe i uczciwe interesy, oparte na wzajemnym zaufaniu. Tak wyglądają kontakty biznesowe z firmą w Nowym Jorku ${ }^{43}$ i w Chicago ${ }^{44}$. Ale chyba największe wrażenie zrobiły na Bobkowskim dwie rzeczy: ograniczenie biurokracji oraz bezinteresowne porady biznesowe. Amerykanie z trudem dostosowywali się do gwatemalskich formularzy na importowane towary. Natomiast doskonale rozumieli istotę prowadzonej przez siebie działalności handlowej i podpowiedzieli swemu partnerowi, by zapewnił serwis dla swoich wyrobów, a będzie na swoim terenie bezkonkurencyjny.

Obserwacje prowadzone w USA pozwoliły Bobkowskiemu-ekonomiście sformułować jedną z ciekawszych opinii na temat komunizmu. Jest ona wyjątkowo przenikliwa i zdumiewa trafnością w czasach, kiedy wydawało się, że system ten posiada intelektualną przewagę: „Komunizm przy wszystkich pozorach i teoriach dynamizmu marzy o zatrzymaniu rozwoju, o petryfikacji; śni o liczeniu szprych na zatrzymanym kole" ${ }^{45}$. Ta celna metafora zapalonego cyklisty powstała w wyniku obserwacji dynamizmu amerykańskiej przedsiębiorczości. Jednocześnie była dobitnym potwierdzeniem decyzji, aby nie wracać nie tylko do powojennej Polski, ale nawet do Europy.

\section{Bibliografia}

\section{Literatura podmiotu}

Andrzej Bobkowski-Aniela Mieczystawska. Listy 1951-1961, Warszawa 2010.

Bobkowski A., Biografia wielkiego Kosmopolaka, „Kultura” 1960, nr 9 (155), http:// static.kulturaparyska.com/attachments/cb/b0/4389fdd1 ef03ab9dd13faf07db 8cccde93451e83.pdf\#page=11, dostęp: 28.11.2015.

Bobkowski A., Coco de Oro, Paryż-Kraków 2015.

Bobkowski A., Listy do Aleksandra Bobkowskiego 1940-1961, oprac. J. Podolska, Warszawa 2013.

Bobkowski A., Listy do Jerzego Turowicza 1947-1960, oprac. M. Urbanowski, Warszawa 2013.

Bobkowski A., Listy do różnych adresatów, oprac. K. Ćwikliński, Kraków 2013.

${ }^{42}$ A. Bobkowski, $Z$ notatnika modelarza, dz. cyt., s. 179.

43 Tamże, s. 181-182.

${ }^{44}$ Tamże, s. 191-193.

45 Tamże, s. 194. 
Bobkowski A., Listy do Tymona Terleckiego 1956-1961, oprac. N. Tylor-Terlecka, Warszawa 2006.

Bobkowski A., Listy z Gwatemali do matki, red. E. Jurczyszyn, Warszawa 2008.

Bobkowski A., "Tobie zapisuje Europę. Listy do Jarostawa Iwaszkiewicza, oprac. J. Zieliński, Warszawa 2009.

Bobkowski A., Szkice piórkiem (Francja 1940-1944), Londyn 1985.

Bobkowski A., Z dziennika podróży, Warszawa 2013.

Giedroyc J., Bobkowski A., Listy 1946-1961, Warszawa 1997.

\section{Literatura przedmiotu}

Andrzej Bobkowski wielokrotnie, red. K. Ćwikliński, A.S. Kowalczyk, M. Urbanowski, Warszawa 2014.

Ćwikliński K., Andrzeja Bobkowskiego ars epistolandi, „Odra” 1992, nr 6.

Dybciak K., Sztuka bycia wolnym cztowiekiem, „Tygodnik Solidarność” 1996, nr 23.

Kopczyk M., Obecność innego. Studia z literatury wspótczesnej, Bielsko-Biała 2013.

Kowalczyk A.S., Wstęp [w:] Andrzej Bobkowski-Aniela Mieczystawska. Listy 19511961, Warszawa 2010.

Nowak M., Na tuku elektrycznym. O pisaniu Andrzeja Bobkowskiego, Warszawa 2014.

Stabro S., Andrzej Bobkowski - biografia symboliczna, „Ruch Literacki” 1993, z. 4.

Stabro S., Europa odrzucona, „Twórczość” 1991, nr 9.

Urbanowski M., Krzyk chuligana, „Arcana” 1995, nr 4.

Urbanowski M., Szczęście pod wulkanem, „Nowe Państwo” 2001, nr 24.

Zagańczyk M., Najpierw żyć, „Kultura Niezależna” 1990, nr 59.

Zieliński J., Ode mnie przynajmniej listy cośsa warte (o listach Andrzeja Bobkowskiego do rodziny), „Twórczość” 1984, nr 8.

Zieliński J., Wielki spokój, „Teksty Drugie” 1991, nr 1-2. 